\title{
Impact of Temperature on Autumn- and Spring-initiated Inflorescence Systems within a Biennial Pruning System of Protea 'Pink Ice' Cut Flowers
}

\author{
Eugenie-Lien Louw ${ }^{1}$, Eleanor W. Hoffman, Karen I. Theron, \\ and Stephanie J. E. Midgley \\ Department of Horticultural Science, Stellenbosch University, Private Bag \\ X1, 7602 Matieland, Stellenbosch, South Africa
}

Additional index words. gas exchange, climate change, phenology, Proteaceae, reproductive response, vegetative growth

\begin{abstract}
The potential impact of increasing temperatures driven by climate change on cultivated Protea cut flower production systems is not known. This study used a biennial pruning system in Protea 'Pink Ice' to track the physiological and reproductive responses in comparable phenological stages, but exposed to different seasonally determined temperature conditions. Protea 'Pink Ice' generally initiates inflorescences terminally on the spring flush. A limited number of shoots can initiate inflorescences on the preceding autumn flush, leading to an advanced harvesting time compared with that of the springinitiated inflorescences. In a commercial Protea orchard in Hopefield, South Africa, gas exchange, carbohydrate availability, and vegetative and reproductive growth were compared between the two shoot types in the context of seasonal temperature differences. Leaves of shoots, which initiated inflorescences on the autumn flush, generally had higher light-saturated net carbon dioxide $\left(\mathrm{CO}_{2}\right)$ assimilation capacities in autumn (April-May) and spring (October-November). There is evidence of a requirement of minimum shoot diameter of $7.6 \mathrm{~mm}$ (four- or five-flush shoot), as measured directly above the intercalation between the terminal (uppermost mature flush) and subterminal flush, when the subsequent flush was at budbreak stage during April (autumn) and at least five flushes to be required for floral initiation in Protea 'Pink Ice'. Spring-initiated inflorescences had a shorter developmental period (4 months) than that of autumninitiated inflorescences ( 7 months) and developed into significantly smaller (width) inflorescences with a lower width and dry weight at harvest. These inflorescences were harvested on average a month later compared with autumn-initiated inflorescences. The ambient temperature during inflorescence development played a significant role in the inflorescence growth rate, affecting the time required from visible inflorescence detection to harvest. At the calculated optimum base temperature of $9{ }^{\circ} \mathrm{C}$, autumn-initiated inflorescences required 41,010 growing degree hours (GDH), whereas spring-initiated inflorescences required 35,872 GDH from initiation to anthesis. Under future warmer growing conditions, anticipated decreased size and dry weight of inflorescences may reduce marketability and income for Protea producers.
\end{abstract}

The Western Cape region of South Africa, where Proteaceae have traditionally been cultivated as cut flower products, has a Mediterranean-type climate with warm, dry summers with minimum and maximum temperatures of 9.3 and $41.3{ }^{\circ} \mathrm{C}$ in JanuaryFebruary and cool, wet winters from June to August with a minimum of $0.8{ }^{\circ} \mathrm{C}$ and maximum of $28.9{ }^{\circ} \mathrm{C}$. Elevated mean annual temperatures of up to $+4.5^{\circ} \mathrm{C}$ by midcentury relative to the base period (1981-2010), with

\footnotetext{
Received for publication 6 Nov. 2017. Accepted for publication 10 Jan. 2018.

This research was financially supported by Cape Flora SA (CFSA), the National Research Foundation (NRF), and Stellenbosch University.

${ }^{1}$ Corresponding author. E-mail: eugenie@arnelia. co.za.
}

both higher minimum and maximum temperatures, as well as more frequent and more intense heat waves are projected in climate change models (Midgley et al., 2016). Already, the Western Cape has experienced a drastic rate of increase in daily maximum temperature of around $0.2{ }^{\circ} \mathrm{C}$ per decade, as recorded over the 1960-2010 period (Midgley et al., 2016). As expected, changes in rainfall are far more complex; nonetheless, climate change is likely to result in a reduction in surface water availability and cause potential shifts in seasonality of rainfall and an increase in the magnitude and frequency of flood events (Midgley et al., 2016).

The potential impact of increasing temperatures due to climate change on cultivated Protea inflorescence production is unknown. A study by Louw et al. (2015) investigated gas exchange and growth of Protea 'Pink Ice' under increased temperatures and found increased leaf dry weight per unit area with increasing temperature, which indicated leaf structural changes. Leaf area-based gas exchange [net $\mathrm{CO}_{2}$ assimilation rate, stomatal conductance $\left(g_{\mathrm{S}}\right)$, and dark respiration rate] did not differ across the temperature gradient, but leaf weight-based $\mathrm{CO}_{2}$ assimilation rate and dark respiration rate decreased significantly toward the upper end of the temperature range. Under warming, spring budbreak occurred earlier, but inflorescence initiation extended from the spring flush to the summer flush, leading to delayed flowering. In addition, with warming, aboveground biomass allocation patterns were altered whereby less carbon is invested into the inflorescences and more carbon is invested in the leaves and, to a lesser degree, stems. The study by Louw et al. (2015) suggests that warming may prolong the vegetative growth period in some Protea cultivars, at the expense of flower production. However, large gaps still remain in our understanding of responses within such systems under enhanced environmental stress. In addition, cut flower production of Protea and other genera within the Proteaceae is increasingly viewed as potential alternative crops in South Africa, particularly in areas regarded as too warm for most temperate horticultural crops such as apples and pears. This further justifies the need to understand the response of the vegetative and reproductive growth of Protea under warmer conditions than those prevalent in current production areas.

The demand for Protea cut flowers in Europe peaks during the European autumn and winter, from September to February (Gerber et al., 2001a; Hettasch et al., 1997). Unlike Leucospermum (Malan and Jacobs, 1990) and Leucadendron (Hettasch and Jacobs, 2006), which are short-day plants, the underlying mechanism for floral induction in Protea has not been established. In the southern hemisphere, Protea 'Pink Ice' (Protea compacta $\mathrm{R}$. $\mathrm{Br} \times$ Protea susannae Phill.) generally initiates inflorescences on the spring flush (September-October), and the harvest stage is reached from January to May (Gerber, 2000), falling mostly outside of the optimum export period. Together with the harvest time, a minimum stem length and an unblemished bloom determine the quality and price of these niche market cut flowers (Hettasch et al., 1997). The combined vegetative and reproductive cycles of 'Pink Ice' extend over 14-16 months. Commercially, flowering time in Protea can be manipulated by pruning (Greenfield et al., 1994; Nieuwoudt and Jacobs, 2010). A biennial bearing cycle with two blocks in alternating phases is recommended for commercial production (Gerber et al., 1995; Hettasch et al., 1997). This biennial management system ensures that inflorescences borne on long stems can be harvested annually, albeit from different blocks, and provides for a sustained income.

In a South African biennial bearing cycle, Protea 'Pink Ice' is pruned back to a basal 
bearer in winter (June/July). New growth initiates during spring in late August, and vegetative growth continues by means of several growth flushes through the summer and autumn of the first year. Flower initiation only commences during the spring of the second year, with the subsequent harvest in the summer/autumn of that season. It was observed that, in a biennial cycle, a limited number of 'Pink Ice' shoots initiate inflorescences terminally on the autumn flush, $\approx 9-10$ months after pruning (E.-L. Louw, personal communication; Nieuwoudt and Jacobs, 2010). These long-stemmed autumninitiated inflorescences reach the European market from December to February, within the period of high demand, thus optimizing the price per stem.

As little information is available on how temperature affects commercial Protea cultivation, especially floral induction and initiation, the different inflorescence initiation systems within 'Pink Ice' provide the ideal opportunity to study the effect of postinitiation temperature on leaf gas exchange, vegetative growth, and inflorescence growth patterns in comparable phenological stages.

The aim of this study was to compare the two distinctly different inflorescence initiation systems in Protea 'Pink Ice' as managed within a biennial bearing regime, with respect to the temperature sensitivity of inflorescence development and quality. The more common spring-initiated system was compared with the more preferred out of season autumn-initiated system, in the context of different seasonal temperature regimes. This would provide an indication of future shifts in inflorescence production and profitability that would be expected under projected climate change.

\section{Materials and Methods}

Experimental site and pruning system. A 6-year-old Protea 'Pink Ice' plantation at Arnelia Farms, Hopefield, South Africa $\left(33^{\circ} 02^{\prime} \mathrm{S} ; 18^{\circ} 20^{\prime} \mathrm{E}\right)$ was selected as the experimental site. The soil was classified as Namib form, Nortier family. The plants grew in a double row system, spaced $2.2 \times 1 \mathrm{~m}$ within the rows, with a $3.5 \mathrm{~m}$ service way in a north-east to south-west row orientation. In-line fertigation using a drip irrigation system was supplied, weekly during winter, and was increased progressively to once a day during summer, according to commercial growers' practice to ensure adequate irrigation for the duration of the trial.

Plants were managed according to a biennial bearing and pruning system (Gerber et al., 1995; Hettasch et al., 1997). Plants in the vegetative phase ("off block") were selected and pruned back to 20 bearers per plant in July 2007. Newly sprouting lateral buds were thinned to two remaining shoots per bearer in Nov. 2007, allowing 40 harvestable shoots to develop per plant. On $10 \mathrm{Apr}$. 2008, 30 four- or five-flush shoots and 30 two- or three-flush shoots were tagged, respectively, on randomly selected plants in a single row within the block. This selection was made to include both vigorous shoots that may have the capacity to initiate inflorescences on the autumn flush (autumninitiated inflorescences) and shoots of a perceived lower quality that will require the later more vigorous spring flush to initiate an inflorescence (spring-initiated inflorescences).

Vegetative measurements. Baseline measurements: shoot length measured from the point of inception on the bearer $(\mathrm{cm})$, shoot diameter $(\mathrm{mm})$ measured directly above the intercalation between the terminal (uppermost mature flush) and subterminal flush, when the subsequent autumn flush was at budbreak stage, total number of flushes on the shoot, and number of leaves per flush were recorded on 10 Apr. 2008 (autumn) on 30 tagged shoots of each shoot type. Thereafter, shoot growth and timing of inflorescence initiation (autumn- or spring-initiated) and the progression of inflorescence development were recorded biweekly, except during the winter of 2008 when data were recorded every 4 weeks as no visible active growth was detected. The fate of the terminal bud was unknown when shoots were selected and only seven of the vigorous shoots initiated inflorescences on the autumn flush. Data collection proceeded only on the initial selected 30 four- or five-flush vigorous shoots from 30 July 2008 onward. Lateral shoots sprouting in axillary positions after inflorescence initiation were removed by hand as early as possible, as is the commercial practice.

Gas exchange. Leaf gas exchange measurements were taken with a LI-6400 Portable Photosynthesis System (LI-COR, Lincoln, $\mathrm{NE}$ ) of intact leaves in the uppermost mature flush. $A_{\max }$ (the maximum rate of lightsaturated net $\mathrm{CO}_{2}$ assimilation) was measured under photosynthetic photon flux density (PPFD) and $\mathrm{CO}_{2}$ levels of 2000 $\mu \mathrm{mol} \cdot \mathrm{m}^{-2} \cdot \mathrm{s}^{-1}$ and $380 \mu \mathrm{mol} \cdot \mathrm{mol}^{-1}$, respectively. Stomatal conductance was measured concurrently. The maximum rate of lightand $\mathrm{CO}_{2}$-saturated net $\mathrm{CO}_{2}$ assimilation $\left(A_{\text {sat }}\right)$ was measured at $2000 \mu \mathrm{mol} \cdot \mathrm{m}^{-2} \cdot \mathrm{s}^{-1}$ PPFD and $1200 \mu \mathrm{mol} \mathrm{CO} / \mathrm{mol}$. Dark respiration rate $\left(R_{\mathrm{d}}\right)$ was measured with $\mathrm{CO}_{2}$ set at $380 \mu \mathrm{mol} \cdot \mathrm{mol}^{-1}$ and the light-emitting diode light turned off. PPFD of 2000 $\mu \mathrm{mol} \cdot \mathrm{m}^{-2} \cdot \mathrm{s}^{-1}$ was used throughout the study to eliminate variation caused by changes in time of day and year and cloud cover and to ensure full photosynthetic capacity under nonlimiting light conditions.

Gas exchange measurements were taken on a single leaf of the terminal flush of 15 tagged shoots per shoot type, on the same day as the vegetative measurements. From 30 July 2008 onward gas exchange measurements were taken on a single intact leaf of the terminal mature flush of the seven autumn-initiated shoots and the 23 spring-initiated shoots.

On 30 Oct. 2008, the photosynthetic response to intercellular $\mathrm{CO}_{2}$ concentration $\left(A / c_{i}\right.$ response curves) was measured with the irradiance (PPFD) set at $2000 \mu \mathrm{mol} \cdot \mathrm{m}^{-2} \cdot \mathrm{s}^{-1}$.
The cuvette $\mathrm{CO}_{2}$ concentration was initially set at $1200 \mu \mathrm{mol} \cdot \mathrm{mol}^{-1}$, where after it was sequentially lowered $(1000,750,500,380$, $250,170,100,75$, and $\left.50 \mu \mathrm{mol} \cdot \mathrm{mol}^{-1}\right)$. For these measurements, a single intact leaf on the terminal flush was selected from four shoots per inflorescence initiation shoot type.

$A / c_{i}$ response curves were fitted individually using an advanced nonlinear estimation (Statistica 8.0; Statsoft, Inc., Tulsa, OK) and the monomolecular function $y=a\left[1-\mathrm{e}^{(b-c x)}\right]$ as described by Causton and Dale (1990). The fitted curve coefficient " $a$ " represented the rate of light- and $\mathrm{CO}_{2}$-saturated net $\mathrm{CO}_{2}$ assimilation $\left(A_{\text {sat }}\right)$, " $b / c$ " represented the $\mathrm{CO}_{2}$ compensation point, "ace ${ }^{b}$ " represented the apparent carboxylation efficiency (the slope of the $A / c_{i}$ response curve at $x=0$ ), and the predicted photorespiration rate $\left(R_{\text {day }}\right)$ was calculated using " $a\left(1-\mathrm{e}^{b}\right)$ " (Causton and Dale, 1990).

Total nonstructural carbohydrate determination. Concurrent with gas exchange measurements throughout the season, 25 leaves were harvested in the afternoon from shoots comparable (number of flushes and shoot diameter) with the tagged shoots on which gas exchange measurements were performed. Leaves were selected from the uppermost mature flush. Leaf length $(\mathrm{mm})$, width $(\mathrm{mm})$, area $\left(\mathrm{cm}^{2}\right)$ (Portable Area Meter, Li-3000A; LI-COR), along with fresh and dry weight $(\mathrm{g})$ [Forced circulation incubator, FSIE 16; Labcon (Pty) Ltd., Roodepoort, South Africa] were determined. Twenty-five leaves per inflorescence initiation system were pooled into groups of five, and subsequently, five leaves was used to represent a sample $(n=5)$. The oven-dried leaves were milled and stored at $-20{ }^{\circ} \mathrm{C}$ until sugar analysis and starch analysis were performed.

Total soluble sugars were extracted using $80 \%$ ethanol extraction, a method described by Allen et al. (1974) and Hamid et al. (1985). Starch was hydrolyzed to glucose using an acetic acid buffer method and amyloglucosidase enzyme (Hamid et al., 1985). Final sugar and starch concentrations were obtained by means of an adapted spectrophotometric method (Dische, 1962), as described by Reed et al. (2004), where anthrone was used as a colorimetric agent. Sample absorbance was read with a Cary 50 Bio ultraviolet-visible spectrophotometer (Varian; Varian Australia Pty Ltd., Victoria, Australia) at $620 \mathrm{~nm}$ against a blank consisting of deionized water and anthrone, with glucose as a standard for quantification.

Harvest. Flowering shoots were harvested from Dec. 2008 to Mar. 2009, at the commercial "soft tip" stage, cut at the point of inception to include the entire basal flush. Shoot length $(\mathrm{cm})$, shoot diameter $(\mathrm{mm})$ measured directly above the intercalation between the terminal (flush below the inflorescence) and subterminal flush, and the final number of flushes were determined. The length of each flush $(\mathrm{cm})$, number of leaves per flush, total leaf area per flush $\left(\mathrm{cm}^{2}\right)$ (Portable Area Meter, Li-3000A; LI-COR), and the fresh and dry weight $(\mathrm{g})$ of the stem 


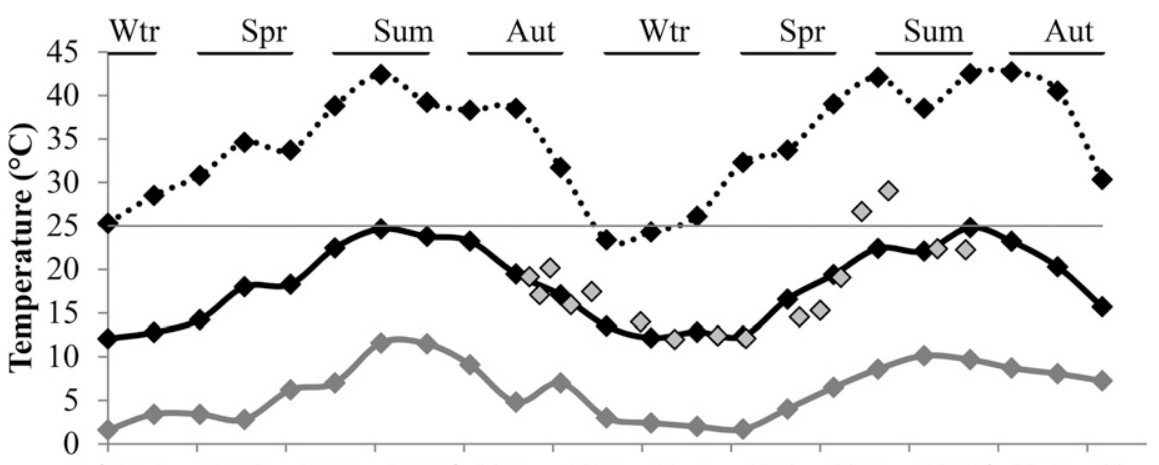

Jul-07 Aug-07 Oct-07 Dec-07 Feb-08 Apr-08 Jun-08 Aug-08 Oct-08 Dec-08 Feb-09 Apr-09 Months (2007-2009)

\section{$\neg$ Mean $\cdots \bullet$ Maximum $\neg$ Minimum $\diamond$ Measurement days $-25^{\circ} \mathrm{C}$}

Fig. 1. Monthly mean, maximum and minimum temperatures $\left({ }^{\circ} \mathrm{C}\right)$ from July 2007 to May 2009 , and mean temperatures of the days on which gas exchange measurements were performed on 6-year-old Protea 'Pink Ice' shoots. Data were obtained from the Agricultural Research Council weather station at Koperfontein, $10 \mathrm{~km}$ from the experimental site at Arnelia Farms. The maximum and minimum temperature value was recorded per month, whereas the mean temperature is the calculated mean monthly temperature using mean daily temperatures. The line inserted at $25^{\circ} \mathrm{C}$ enables a temperature comparison between the respective years. The seasons of the Southern Hemisphere is indicated with $\mathrm{Wtr}=$ winter; $\mathrm{Spr}=$ spring; Sum $=$ summer; Aut $=$ autumn .

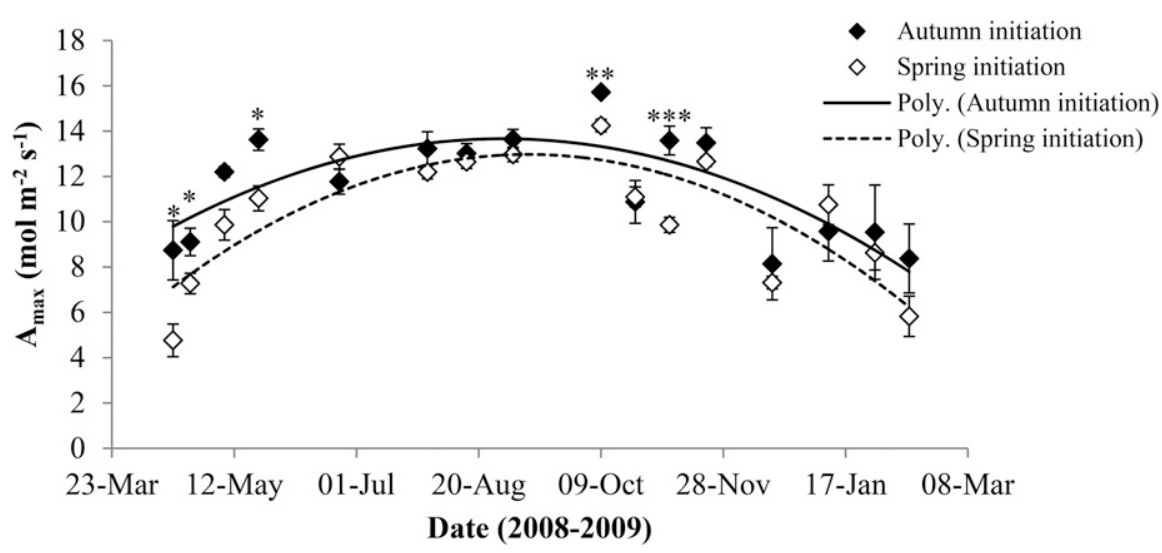

Fig. 2. Maximum rate of light-saturated net $\mathrm{CO}_{2}$ assimilation $\left(A_{\max }\right) \pm \mathrm{sE}$ recorded in 6-year-old Protea 'Pink Ice' shoots from Apr. 2008 to Feb. 2009. These shoots initiated inflorescences terminally on either the autumn $(n=7)$ or spring $(n=23)$ flush. * Significantly different at $P<0.05$; ** significantly different at $P<0.01 ; * * *$ significantly different at $P<0.001$.

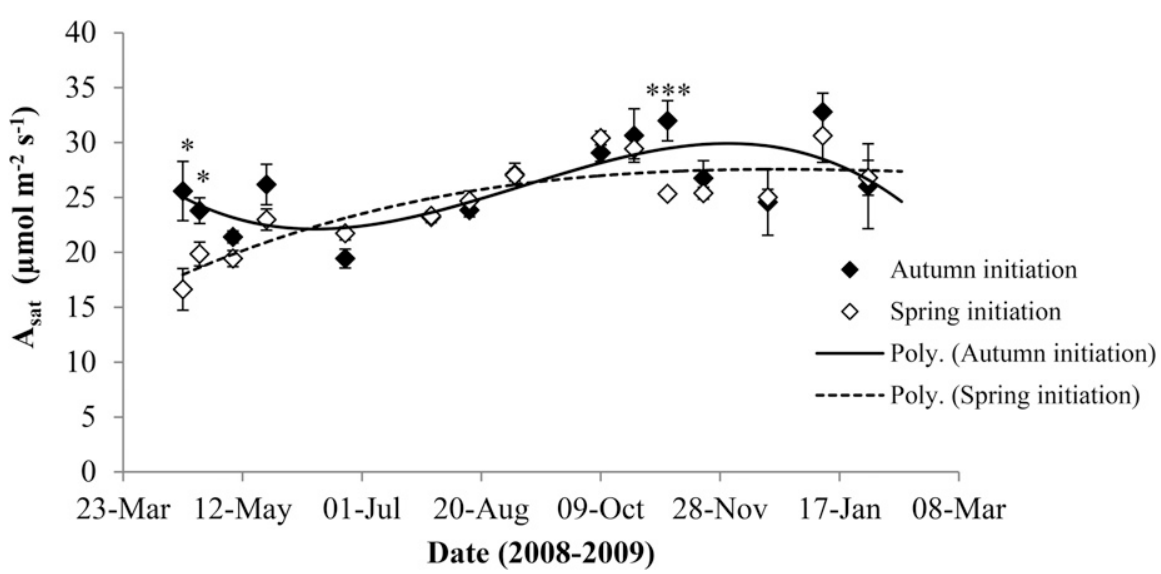

Fig. 3. Light- and $\mathrm{CO}_{2}$-saturated rate of net $\mathrm{CO}_{2}$ assimilation $\left(A_{\text {sat }}\right) \pm \mathrm{SE}$ recorded on 6-year-old Protea 'Pink Ice' shoots from Apr. 2008 to Feb. 2009. These shoots initiated inflorescences terminally on either the autumn $(n=7)$ or spring $(n=23)$ flush. *Significantly different at $P<0.05$; ** significantly different at $P<0.01 ; * * *$ significantly different at $P<0.001$. and leaves per flush were recorded. Separated leaves and stems were dried at $60^{\circ} \mathrm{C}$ in a draft oven [Forced circulation incubator, FSIE 16; Labcon (Pty) Ltd.]. Inflorescence length (mm) and width $(\mathrm{mm})$ were measured, where after it was dissected into bracts, florets, and receptacles of which fresh and dry weight $(\mathrm{g})$ were recorded.

Ambient air temperature and heat units. Hourly air temperatures $\left({ }^{\circ} \mathrm{C}\right)$ were obtained from the Koperfontein Agricultural Research Council (ARC) weather station $\left(33^{\circ} 06^{\prime} \mathrm{S}\right.$; $18^{\circ} 24^{\prime} \mathrm{E}$ ), within $10 \mathrm{~km}$ of the experimental site. Monthly mean, maximum, and minimum temperatures from July 2007 to May 2009 and temperatures on the days when gas exchange measurements were recorded are presented (Fig. 1).

The heat unit requirements for two phenological stages, budbreak to the cessation of shoot growth and inflorescence development from visible inflorescence detection to commercial harvest stage were calculated. The mean date for each phenological stage per area/system was used in the calculation. Heat units were calculated as GDH where,

$\mathrm{GDH}=\left[\right.$ Measured mean hourly temperature $\left.\left(T_{\mathrm{m}}{ }^{\circ} \mathrm{C}\right)\right]$

- [Base temperature $\left.\left(T_{\mathrm{b}}{ }^{\circ} \mathrm{C}\right)\right]$,

with $\mathrm{GDH}=0$ when $T_{\mathrm{b}}>T_{\mathrm{m}}$ as negative values are not associated with plant growth.

An upper temperature limit of $35^{\circ} \mathrm{C}$ was selected as growth was likely to have ceased at these temperatures and above. The optimum base temperature $\left(T_{\mathrm{b}}\right)$ for each phenological stage was identified as the tempe rature where the GDH sum displayed the minimum CV (Arnold, 1959). Along with the data collected in this experiment, data from three other trials on 8-year-old 'Pink Ice' plants at an experimental site in Stellenbosch (Floraland-Etshwaleni farm, 33 $54^{\prime} 19^{\prime \prime} \mathrm{S}$; $18^{\circ} 48^{\prime} 5^{\prime \prime} \mathrm{E}$ ) were used in the calculation of the heat units, together with air temperature recordings from the $\mathrm{ARC}$ weather station at Nietvoorbij (Stellenbosch, 33 ${ }^{\circ} 54^{\prime}$ 53" S; $\left.18^{\circ} 51^{\prime} 39^{\prime \prime} \mathrm{E}\right)$. The Protea 'Pink Ice' plants at Floraland-Etshwaleni farm, managed in an annual cropping system, were planted in a five row system, in a north-south row direction, spaced $1.5 \times 1.5 \mathrm{~m}$ within rows with a $3 \mathrm{~m}$ service way. The soil was classified as Oakleaf form, Cooper family. Plants were not irrigated from Aug. to Oct. 2008 as the seasonal rainfall and soil moisture levels were considered sufficient. Plants within well-drained rows were selected. Irrigation was supplied throughout summer and into autumn. Granular potassium sulfate was applied during winter and spring.

Statistical analysis. Data obtained from spot gas exchange measurements, the $A / c_{i}$ curves, and harvest parameters were analyzed using analysis of variance using the PROC GLM (SAS Institute Inc., 2003), and mean separation of least significant difference were performed at $P<0.05$.

\section{Results}

Gas exchange. Maximum rate of lightsaturated net $\mathrm{CO}_{2}$ assimilation $\left(A_{\max }\right)$ reached peak values from midwinter to 


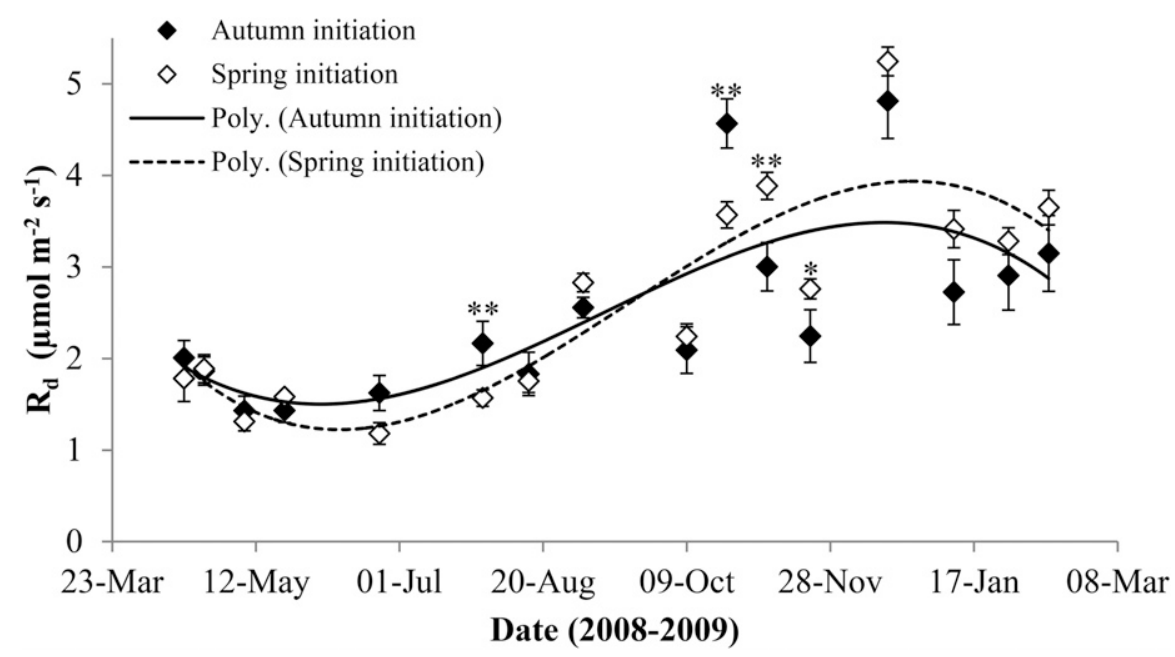

Fig. 4. Dark respiration rate $\left(R_{\mathrm{d}}\right) \pm$ SE recorded on 6-year-old Protea 'Pink Ice' shoots from Apr. 2008 to Feb. 2009. These shoots initiated inflorescences terminally on either the autumn $(n=7)$ or spring $(n=$ 23) flush. *Significantly different at $P<0.05$; **significantly different at $P<0.01$; *** significantly different at $P<0.001$.

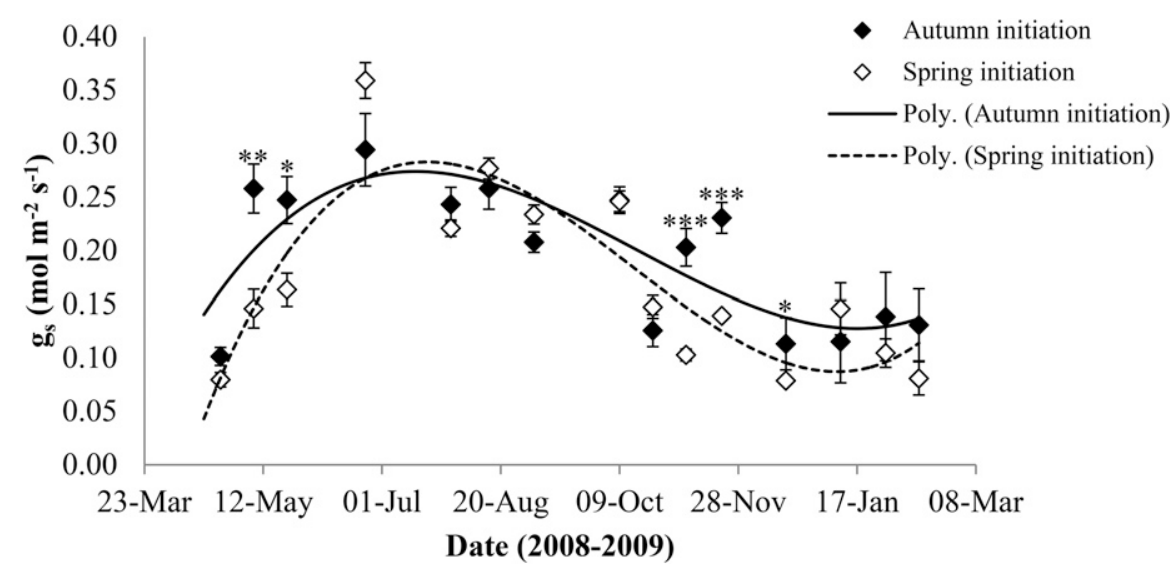

Fig. 5. Stomatal conductance $\left(g_{\mathrm{S}}\right) \pm$ SE recorded on 6-year-old Protea 'Pink Ice' shoots from Apr. 2008 to Feb. 2009. These shoots initiated inflorescences terminally on either the autumn $(n=7)$ or spring $(n=$ 23) flush. *Significantly different at $P<0.05 ; * *$ significantly different at $P<0.01$; *** significantly different at $P<0.001$.

Table 1. Gas exchange capacity derived from $A / c_{i}$ curves as recorded on 30 Oct. 2008 on individual intact leaves of the terminal flush of Protea 'Pink Ice' flowering shoots, for inflorescences initiated either on the autumn or spring flush. Values \pm SE are indicated.

\begin{tabular}{lcccc}
\hline $\begin{array}{l}\text { Flush subtending } \\
\text { the inflorescence }\end{array}$ & $\begin{array}{c}\text { Modeled } A_{\text {sat }} \\
\left(\mu \mathrm{mol} \cdot \mathrm{m}^{-2} \cdot \mathrm{s}^{-1}\right)^{\mathrm{z}}\end{array}$ & $\begin{array}{c}\text { Compensation } \\
\text { point }\left(\mu \mathrm{mol} \cdot \mathrm{mol}^{-1}\right)\end{array}$ & $\begin{array}{c}\text { Apparent carboxylation } \\
\text { efficiency }\left(\mathrm{mol} \cdot \mathrm{m}^{-2} \cdot \mathrm{s}^{-1}\right)\end{array}$ & $\begin{array}{c}\text { Predicted } R_{\text {day }} \\
\left(\mu \mathrm{mol} \cdot \mathrm{m}^{-2} \cdot \mathrm{s}^{-1}\right)^{\mathrm{y}}\end{array}$ \\
\hline Autumn & $44.8 \pm 1.4 \mathrm{a}^{\mathrm{x}}$ & $73 \pm 12 \mathrm{a}$ & $0.157 \pm 0.03 \mathrm{a}$ & $10.5 \pm 1.6 \mathrm{a}$ \\
Spring & $38.2 \pm 2.5 \mathrm{~b}$ & $72 \pm 15 \mathrm{a}$ & $0.132 \pm 0.02 \mathrm{a}$ & $9.1 \pm 1.3 \mathrm{a}$ \\
$\operatorname{Pr}>F$ & 0.0221 & 0.9710 & 0.2729 & 0.5645 \\
\hline
\end{tabular}

${ }^{\mathrm{z}}$ Rate of light- and $\mathrm{CO}_{2}$-saturated net $\mathrm{CO}_{2}$ assimilation.

${ }^{\mathrm{y}}$ The predicted photorespiration rate.

${ }^{\mathrm{x}}$ Treatments with different letters differ significantly at least significant difference, $P<0.05$.

Table 2. Baseline shoot length $(\mathrm{cm})$ and diameter $(\mathrm{mm}) \pm \mathrm{SE}$, recorded on 10 Apr. 2008, on four- to fiveflush shoots before visible inflorescence detection. The measurement was taken directly above the intercalation between the terminal (uppermost mature flush) and subterminal flush when the subsequent autumn flush was at budbreak stage, on shoots which were destined to flower later on either the autumn $(n=7)$ or spring flush $(n=23)$.

\begin{tabular}{lccc}
\hline Flush subtending the inflorescence & Number of shoots $(n)$ & Shoot length $(\mathrm{cm})$ & Shoot diam $(\mathrm{mm})$ \\
\hline Autumn & 7 & $70.0 \pm 1.8 \mathrm{a}^{\mathrm{z}}$ & $7.9 \pm 0.3 \mathrm{a}$ \\
Spring & 23 & $70.3 \pm 1.4 \mathrm{a}$ & $7.5 \pm 0.1 \mathrm{~b}$ \\
$\operatorname{Pr}>F$ & & 0.9133 & 0.0463 \\
\hline
\end{tabular}

${ }^{\mathrm{z}}$ Treatments with different letters differ significantly at least significant difference, $P<0.05$
Spring 2008 (Fig. 2). $A_{\max }$ values were frequently higher in the autumn-initiated shoots compared with the spring-initiated shoots, and significantly so on 17 and 24 Apr., 22 May, 9 Oct., and 6 Nov. 2008 (Fig. 2). Light- and $\mathrm{CO}_{2}$-saturated rate of net $\mathrm{CO}_{2}$ assimilation $\left(A_{\text {sat }}\right)$ was the highest from October to January for both shoot types, but significantly higher in autumn-initiated shoots on 17 and 24 Apr. and 6 Nov. 2008 (Fig. 3). Dark respiration $\left(R_{\mathrm{d}}\right)$ values, irrespective of shoot type, were the lowest during May and June 2008 (winter) and the highest from the end of Oct. 2008 to Feb. 2009 (summer) (Fig. 4). The summer period had monthly mean temperatures of $\approx 22$ to $24{ }^{\circ} \mathrm{C}$ and monthly maximum temperatures of $\approx 42{ }^{\circ} \mathrm{C}$. $R_{\mathrm{d}}$ values were significantly higher on autumn-initiated shoots compared with spring-initiated shoots on 30 July and 23 Oct. 2008, but this was reversed on 6 Nov. and 21 Nov. 2008 (Fig. 4). For both shoot types, $g_{\mathrm{S}}$ peaked in June to Aug. 2008, with autumn-initiated shoots being significantly higher than spring-initiated shoots on 8 and 22 May, 6 and 21 Nov., and 18 Dec. 2008 (Fig. 5). The highest $g_{\mathrm{S}}$ values were found to reflect the lowest temperatures during the year. Stomatal conductance trend for both systems are similar; however, for the autumn-initiation system, absolute $g_{\mathrm{S}}$ values are slightly higher during the year and significantly so in autumn and late spring. Both systems are exposed to the same temperature, but are in different phenological phases.

Gas exchange capacity parameters calculated from the $A / c_{i}$ curve recorded on 30 Oct. 2008 showed that the modeled $A_{\text {sat }}$ was significantly higher in autumn-initiated shoots than that in spring-initiated shoots (Table 1). This was also reported for spot $A_{\text {sat }}$ measurements taken on 6 Nov. 2008 (Fig. 3), although the modeled $A_{\text {sat }}$ was higher in absolute terms because of the use of a different methodology. There were no significant differences between autumn- and spring-initiated shoots regarding the $\mathrm{CO}_{2}$ compensation point, apparent carboxylation efficiency, or rate of photorespiration $\left(R_{\text {day }}\right)$ (Table 1).

Vegetative growth. Baseline measurements recorded on 10 Apr. 2008 showed autumn-initiated shoots to have significantly thicker stems than spring-initiated shoots, although stem lengths were similar (Table 2). Elongation of autumn-initiated shoots ceased in June 2008, whereas the remaining shoots produced a spring flush, followed by inflorescence initiation, with the cessation of shoot elongation during Nov. 2008 (Fig. 6).

Reproductive growth. Inflorescences borne on the spring flush followed a linear growth trend for width (Fig. 7A), whereas inflorescence length displayed an exponential growth curve (Fig. 7B). Inflorescences borne on the autumn flush had a slower growth rate during winter and early spring, but a similar growth rate to the spring-initiated inflorescences from Oct. 2008 onward (Fig. 7A). The autumn-initiated inflorescence length also displayed an exponential growth curve (Fig. 7B). 


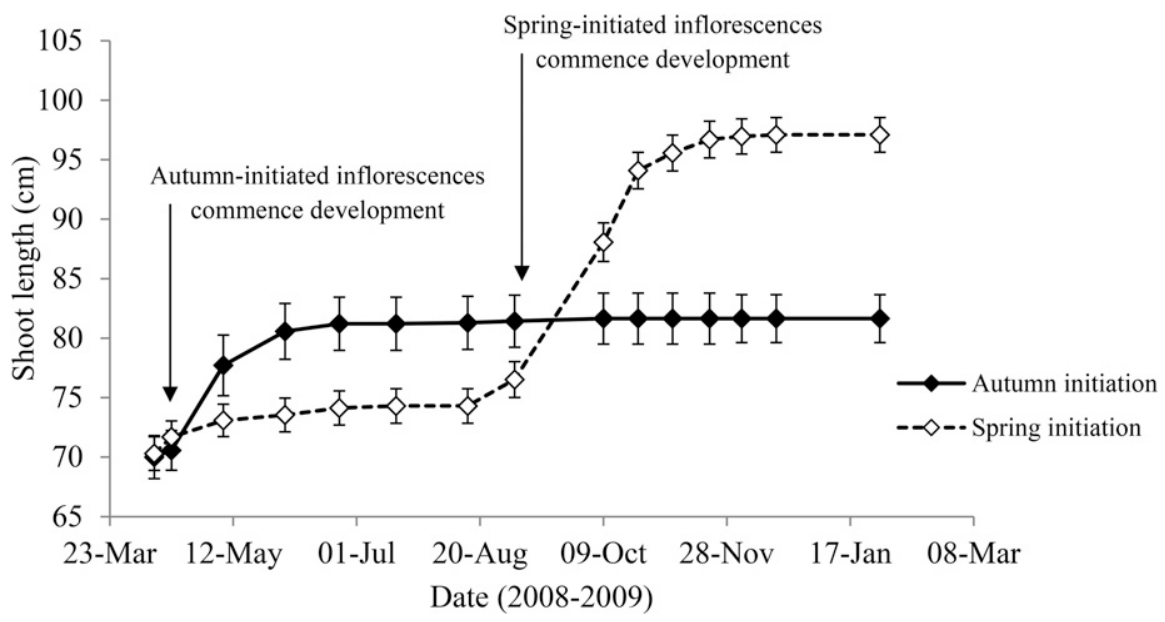

Fig. 6. Vegetative shoot elongation of 6-year-old Protea 'Pink Ice' shoots from Apr. 2008 to Jan. 2009. These shoots initiated inflorescences terminally on either the autumn $(n=7)$ or spring $(n=23)$ flush.
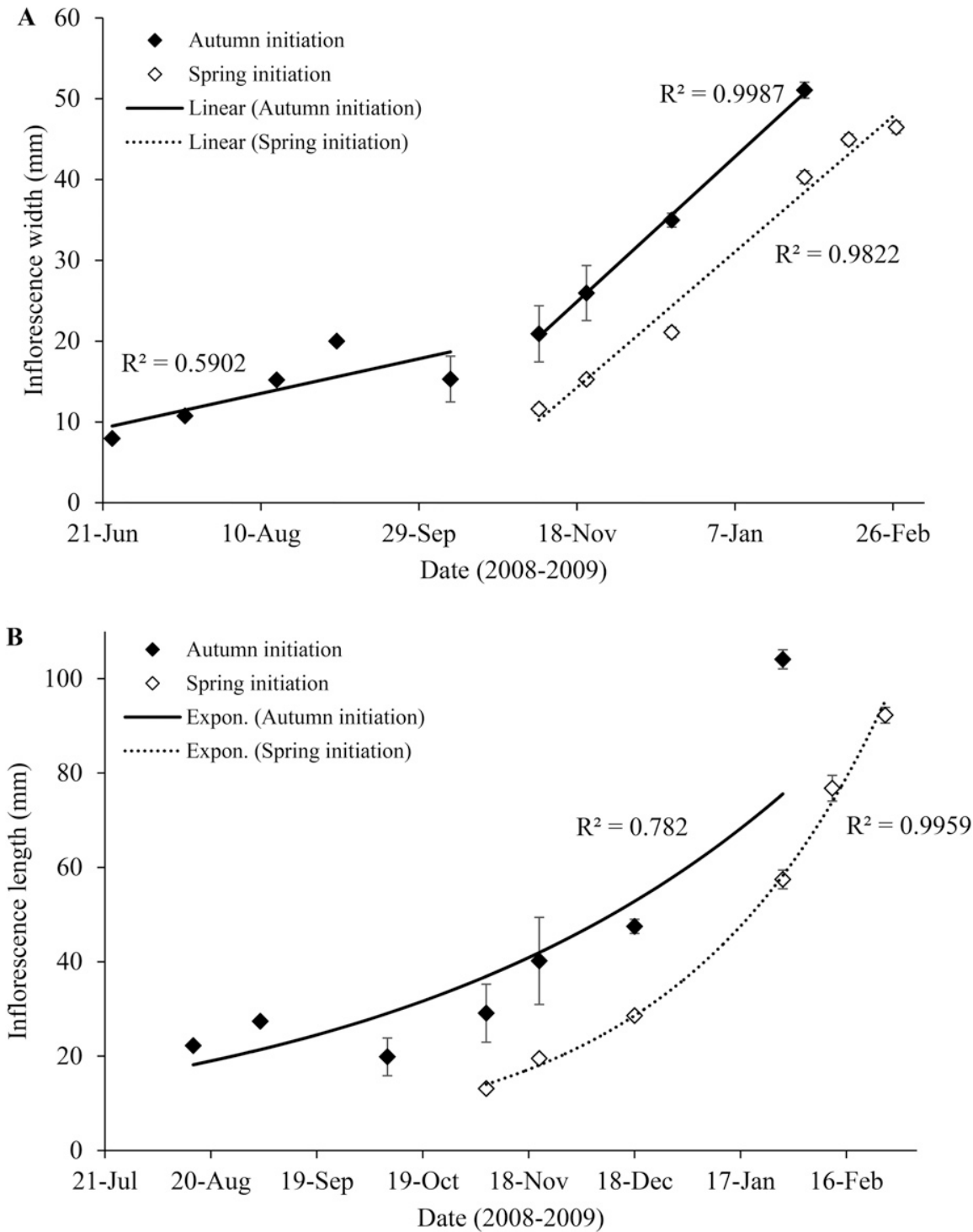

Fig. 7. Inflorescence width \pm SE (A) and length \pm SE (B) of 6-year-old plants of Protea 'Pink Ice' initiated terminally on either the autumn $(n=7)$ or spring $(n=23)$ flush.
All fitted trend lines produced high $R^{2}$ values, except the first linear phase of the autumninitiated width growth.

Harvest. Shoot diameter, stem length, leaf dry weight, and leaf area were significantly higher at harvest in spring-initiated shoots compared with autumn-initiated shoots (Table 3). The harvest date averaged $37 \mathrm{~d}$ earlier for autumn-initiated inflorescences compared with spring-initiated inflorescences (Table 3). Total inflorescence bract, floret, and receptacle dry weight were significantly higher in the autumn-initiated compared with spring-initiated inflorescences, which resulted from significantly wider inflorescences (Table 3).

Heat units. A base temperature for the first phenological phase, budbreak to the end of shoot elongation could not be calculated (data not shown). For the reproductive phenological phase, which ranged from visible detection of the inflorescence to commercial harvest stage, the lowest coefficient of variance was calculated at $9{ }^{\circ} \mathrm{C}$. A total of 41,010 $\mathrm{GDH}$ were required to commercial harvest stage of the autumn-initiated inflorescences, whereas $35,872 \mathrm{GDH}$ were required for spring-initiated inflorescences to reach the "soft tip" stage (Table 4).

Sugar and starch analysis. Leaf total soluble sugar concentration (Fig. 8A) of the terminal flush decreased from $\approx 130$ to $95 \mathrm{mg}$ glucose/g dry weight during winter (Apr. to Aug. 2008) for both shoot types. An increase was reported from Sept. 2008 to harvest, with significantly higher values during summer in autumn-initiated shoots, except on 9 and 23 Oct. 2008 when spring-initiated shoots had higher leaf sugar concentrations. No clear seasonal pattern could be observed in the leaf starch concentrations (Fig. 8B). However, starch values were significantly higher in autumn-initiated shoots compared with spring-initiated shoots on 17 and 24 Apr., 22 May, 17 July, 23 Oct., 6 Nov., and 8 Dec. 2008, whereas on 10 and 29 Jan. 2009 the starch concentration was significantly higher in spring-initiated shoots (Fig. 8B).

\section{Discussion}

Seasonal gas exchange trends were similar in the two different inflorescence initiation systems. However, leaves on autumn-initiated shoots generally had superior or similar absolute gas exchange capacities compared with leaves on shoots with spring-initiated inflorescences. This greater capacity for carbon assimilation was most likely required for these shoots to initiate inflorescences on the autumn flush. Then again, shoots bearing autumn-initiated inflorescences simply may have had a greater photosynthetic capacity to start with, as they initially had significantly thicker stems in Apr. 2008, along with more leaves and a larger total leaf area of the autumn flush. Secondary control of gas exchange was likely at the level of the phenological stage.

During autumn (mid-April to end May) photosynthesis was upregulated in autumninitiated shoots when higher $A_{\text {sat }}$, together 
with higher $g_{\mathrm{S}}$ lead to higher $A_{\max }$, although $R_{\mathrm{d}}$ was low in both shoot types. The increased $g_{\mathrm{S}}$ in autumn of the autumn-initiation system, increases $A_{\max }$ accordingly and possibly enables the floral initiation, and was then upregulated again in late spring when the inflorescence was developing. The springinitiation system shoots have increased leaf area once the spring flush is formed and upregulation is therefore not as essential when compared with the autumn-initiation system.

It is well known that fruiting trees, based on the sink effect, have higher specific rates of photosynthesis (expressed on a leaf area basis) compared with trees with zero crop load (Webster, 2005). It is proposed that, similar to the upregulation of photosynthesis in heavy-bearing fruit crops, the autumn-initiated shoots responded to a large sink; at first, in the form of a rapidly growing shoot, followed by an energy-requiring, developing inflorescence. At the start of autumn, the starch content of autumn-initiated shoots was significantly higher than that of spring-initiated shoots, where after a marked reduction in starch levels was recorded on 22 May, signaling a depletion of starch reserves and reliance on current photosynthates.

In the winter period (June to early September) $A_{\text {max }}$ gradually increased in both shoot types due to a slowly increasing $A_{\text {sat }}$ and peak $g_{\mathrm{S}}$. Initially, starch was low and then increased in both shoot types toward spring, most likely linked to no or little shoot growth in springinitiated shoots, and slow inflorescence growth in autumn-initiated shoots under low temperatures.

In spring (September to early November) rapid shoot growth was documented in spring-initiated shoots, and gradual inflorescence growth in autumn-initiated shoots, together with peak $A_{\max }$ rates in both shoot types under ideal climatic conditions (mean temperatures were 11 to $19{ }^{\circ} \mathrm{C}$, accompanied by mostly sunny days). An upregulation of photosynthesis was found in autumn-initiated shoots $\left(A_{\text {sat }}\right)$, together with higher leaf sugar concentration from 9 Oct. and a higher leaf starch concentration from 23 Oct. This observation was validated during Oct. 2008 by comparative data from $A / c_{i}$ curves, which indicated greater photosynthetic capacity of shoots that initiated inflorescences in autumn. Even though there was no difference in the Rubisco activity (indicated by apparent carboxylation efficiency) or photorespiration rate (indicated by the compensation point of $\mathrm{CO}_{2}$ exchange) of autumn- and springinitiated shoots, the higher $A_{\max }$ and $A_{\text {sat }}$ of autumn-initiated shoots can be ascribed to higher $g_{\mathrm{S}}$ and lower $R_{\mathrm{d}}$ at the end of the spring period. $A_{\text {sat }}$ values in spring-initiated shoots were similar to autumn-initiated shoots during the early spring, probably due to an increased photosynthetic capacity as upregulated by the growth demand of the spring flush as the new developing sink.

$A_{\text {sat }}$ differences between initiation systems are important as increased $A_{\text {sat }}$ during 
A

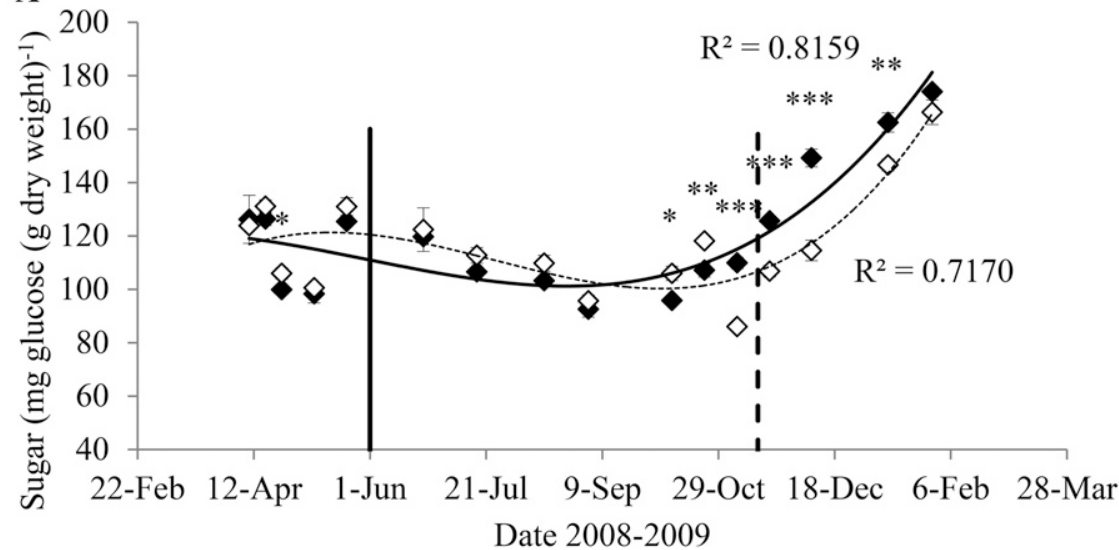

- Autumn initiation

$\diamond$ Spring initiation

Autumn flush inflorescence initiation Poly. (Autumn initiation)

\section{B}

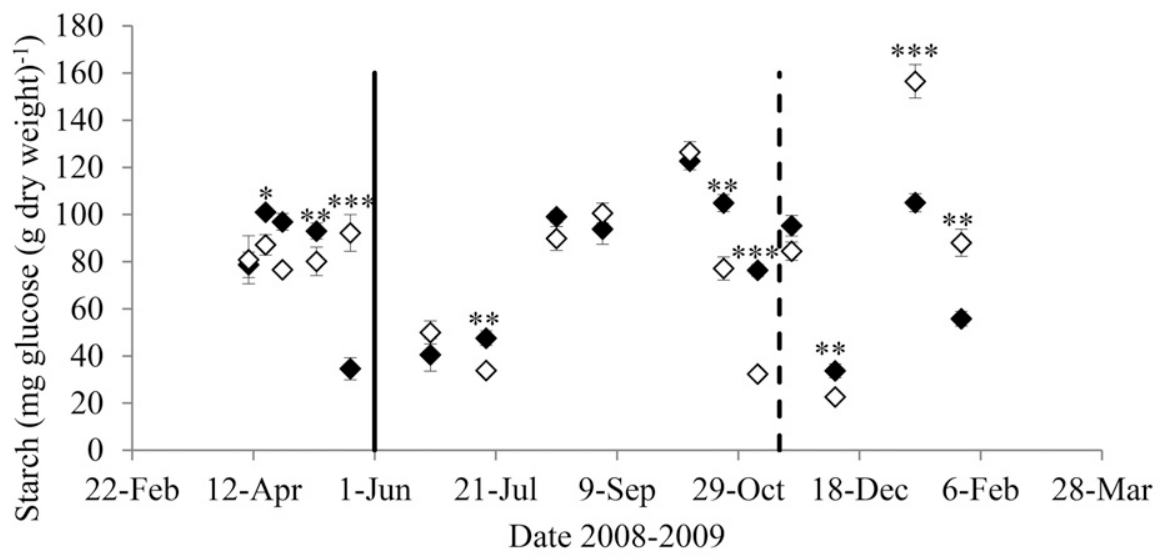

- Autumn initiation

_ Autumn flush inflorescence initation

\section{$\diamond$ Spring initiation}

- - Spring flush inflorescence initation

Fig. 8. The total soluble sugar \pm SE (A) and starch \pm SE concentration (B) expressed in glucose equivalents per gram dry weight as determined for mature leaves of the terminal flush of shoots of 6-year-old Protea 'Pink Ice', sampled from Apr. 2008 to Jan. 2009. *Significantly different at $P<0.05$; **significantly different at $P<0.01 ; * * *$ significantly different at $P<0.001$.

the season implicate higher photosynthetic capacity, which may result in the additional production of sugars and possibly starch, of which a minimum threshold value is thought to be required for a shoot to become reproductive. Therefore, stem diameter is considered a simple indication of carbon capacity and status of the shoot.

From late spring to early summer (midNovember to December) no shoot growth was detected in either shoot type and $g_{\mathrm{S}}$ remained higher in autumn-initiated shoots, but $R_{\mathrm{d}}$ increased in spring-initiated shoots, possibly because of increased sink activity during the summer when the maturation of the spring flush was followed by inflorescence development. Essentially, there was rapid inflorescence growth in both shoot types, although autumn-initiated inflorescences commenced much earlier. During this time, autumn-initiated inflorescences were larger compared with the spring-initiated inflorescences, therefore, requiring more assimilates. Inflorescences first showed growth in width, thereafter growth in length. A higher leaf sugar and starch content in autumn-initiated shoots is reported during the period when final rapid inflorescence growth occurred. The autumn flush subtending the autumn-initiated inflorescence had a third of the leaf area of the spring flush subtending the spring-initiated inflorescence. Therefore, in order for the autumn flush to support an inflorescence slightly larger compared with the spring-initiated inflorescence the upregulation of photosynthesis should be higher compared with that of the spring flush.

In late summer (January-February), during the reproductive phase both shoot types exhibited a similar rate of inflorescence growth, with no shoot growth reported. In this period autumn-initiated shoots recorded a higher concentration of sugars, but with low starch levels, as these might be depleted with the inflorescences reaching a harvestable size and considering the smaller leaf area. However, by comparison, spring-initiated shoots had a higher starch level during their rapid inflorescence growth compared with that of autumn-initiated shoots. The spring flush with a much larger leaf area probably converted additional sugars not used for inflorescence growth and maintenance to starch.

Studies on Protea 'Carnival' (Greenfield et al., 1994) and Banksia (Rieger and Sedgley, 1996) established that vegetative growth is a prerequisite for floral initiation. At least two flushes are considered essential for flowering in Protea (Coetzee and Littlejohn, 2001). The minimum number of flushes is most likely species or cultivar specific. Protea 'Carnival' (Protea neriifolia $\times P$. compacta) initiates inflorescences on two- or three-flush shoots (Greenfield et al., 1994; Hoffman, 2006) and Protea 'Lady Di' (Protea magnifica $\times P$. compacta) initiates inflorescences on twoflush shoots and in exceptional cases on one flush (Gerber et al., 2001b). For 'Pink Ice', a vigorous cultivar, inflorescences are not likely to initiate on three- or four-flush shoots, but rather on a shoot with a minimum of five flushes.

Hoffman (2006) described a minimum shoot diameter requirement of $7 \mathrm{~mm}$ for floral initiation to take effect in "out of season" Protea 'Carnival'. In this study, the shoot diameter differed significantly between the autumn and spring floral initiation systems in Apr. 2008, which emphasizes the minimum vegetative requirement of Protea. The autumn-initiated shoots had a mean shoot diameter of $7.89 \pm 0.3 \mathrm{~mm}$, whereas spring-initiated shoots had a shoot diameter of less than 7.6 mm during Apr. 2008 when shoots were initially selected. Our study suggests a shoot diameter requirement of at least $7.6 \mathrm{~mm}$ in April (autumn) of a four- or five-flush shoot in 'Pink Ice' for inflorescence initiation. This higher minimum shoot diameter threshold in 'Pink Ice' compared with 'Carnival' could possibly be due to cultivar differences and the vigorous growth habit of Protea 'Pink Ice'. Increased growth rate of a vigorous cultivar results in thinner shoots, but with every additional flush, the stem becomes thicker and more likely to flower. Similarly, in Banksia differences in minimum diameter for flowering between species are recognized as $4.5 \mathrm{~mm}$ for Banksia coccinea, $6 \mathrm{~mm}$ for Banksia menziesii, $8 \mathrm{~mm}$ for Banksia hookeriana, and $11 \mathrm{~mm}$ for Banksia baxteri (Sedgley and Fuss, 1992).

A base temperature of $9{ }^{\circ} \mathrm{C}$ was calculated for inflorescence development. This is significantly higher than the $1{ }^{\circ} \mathrm{C}$ recorded for Protea 'Carnival' (Hoffman and Jacobs, 2010) but closer to the $6{ }^{\circ} \mathrm{C}$ recorded for Leucospermum 'Vlam' (Criley et al., 1990). Autumn-initiated inflorescence $(41,010$ GDH) development required $\approx 5000 \mathrm{GDH}$ more than spring-initiated inflorescences (35,872 GDH), whereas Protea 'Carnival' required $54,000 \mathrm{GDH}$ at a base temperature 


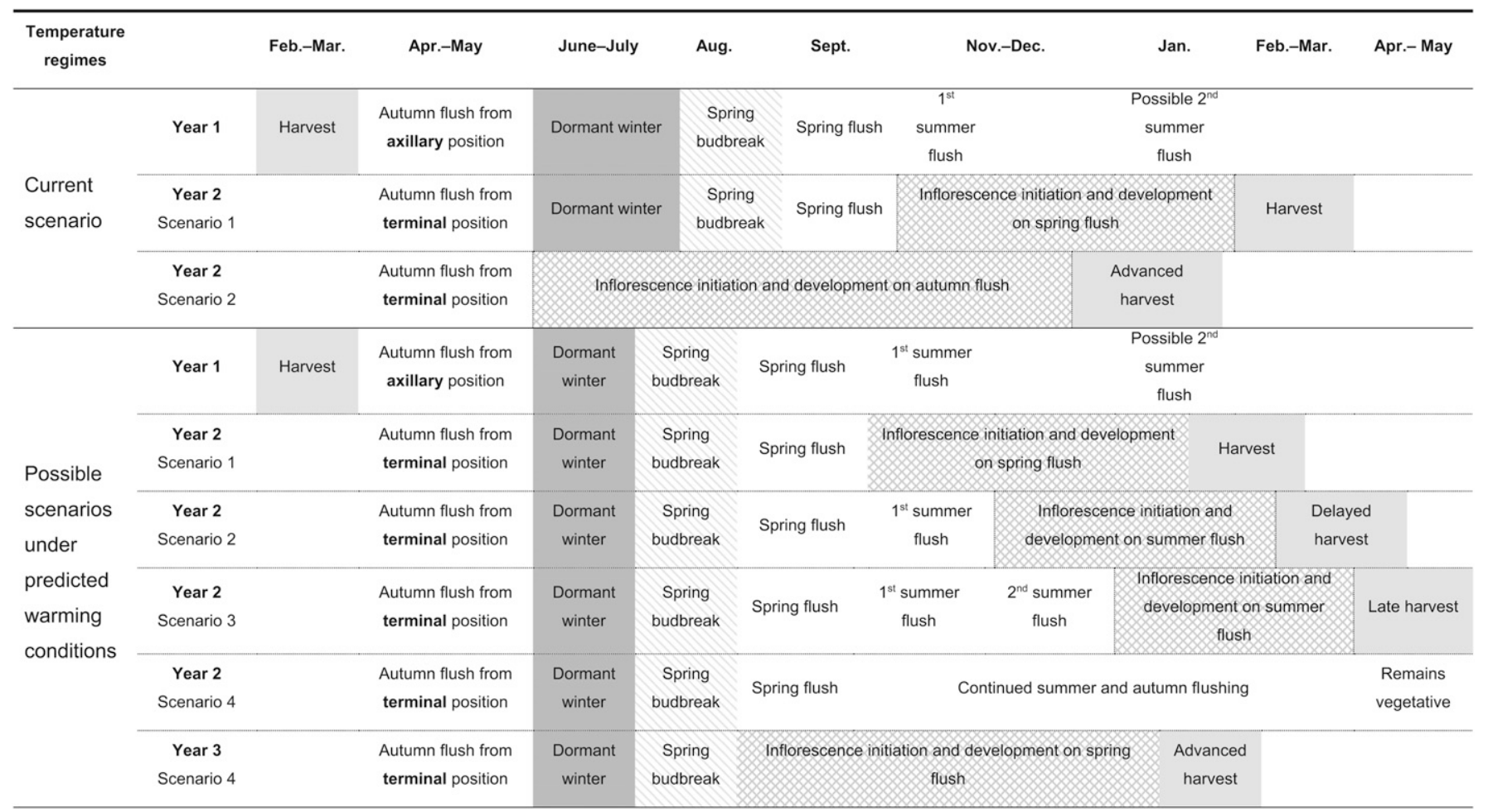

Fig. 9. The scheduling of potential Protea 'Pink Ice' phenological events during the course of an entire season in an unpruned (annual harvesting cycle) system, either when subjected to the current climate or when exposed to predicted warming scenarios. From March to July the sequence of events is similar for all scenarios, but differences become evident with the onset of spring budbreak and onward.

of $1{ }^{\circ} \mathrm{C}$ (Hoffman and Jacobs, 2010). Again, as discussed with minimum shoot diameter requirement for inflorescence initiation, the differences in GDH requirement could be related to the difference in base temperature and cultivar differences. The autumninitiated 'Pink Ice' and 'Carnival' inflorescence, which both developed during the winter period, recorded GDH values closest to each other. The additional GDH required by the autumn-initiated inflorescence compared with spring-initiated inflorescences could be linked to the larger inflorescences produced on the autumn flush and the additional dry weight recorded. The GDH accumulation period also differed significantly between initiation systems. The autumninitiated inflorescences took 3 months (on average $100 \mathrm{~d}$ ) longer to accumulate sufficient GDH compared with the spring-initiated inflorescences. The similar growth rate of both the autumn- and spring-initiated inflorescences from October onward could be linked to increased temperatures during the inflorescence growth period, although the springinitiated inflorescence carried on longer to obtain the commercially harvestable size.

Inflorescence width growth of the springinitiated inflorescence followed a linear curve, whereas the autumn-initiated inflorescence width growth was divided in two linear phases. The first phase showed a slower growth rate during the winter and early spring (July-September), and the second phase showed a faster growth rate from late spring (October-December) onward. Cooler winter temperatures slowed growth rates even while
GDH are being accumulated. Similar data are available for Protea 'Sylvia' and 'Pink Ice' on spring and autumn flushes, respectively (Gerber et al., 2001a; Nieuwoudt and Jacobs, 2010).

In a study where Protea 'Pink Ice' potted plants were grown under a temperature gradient which ranged from ambient to ambient $+4{ }^{\circ} \mathrm{C}$ significant changes in flowering time and inflorescence size under elevated temperatures were recorded (Louw et al., 2015). At the high end of the temperature gradient 'Pink Ice' flowered on the summer flush, rather than on the spring flush as is normally observed. In addition, dry weight allocation shifted to the leaves and then to stems, away from the inflorescences, as inflorescences were smaller with a lower dry weight (Louw et al., 2015). The current study supports findings by Louw et al. (2015) by providing further evidence that inflorescences developing under cooler, milder climates may be larger and assimilate more dry weight compared with inflorescences developing under warmer climates. Spring-initiated inflorescences were generally smaller in size, with a lower bract, floret, and receptacle dry weight. Similarly, roses subjected to heat stress showed a reduction in flower size and petal number (Liang et al., 2017). During the higher temperatures which coincided with the elongation and maturation of the spring flush and inflorescence, lower leaf sugar, but increased starch was recorded and could possibly indicate a shift in biomass allocation. Similar reports emerged from the study by Louw et al. (2015).
In the future, if produced under elevated temperatures, smaller inflorescences may be expected from the same cultivar within the same production area compared with the current production specifications. This possibility has already been observed when inflorescence size and appearance from cooler and warmer areas were compared (G. Nieuwoudt, personal communication). Protea 'Pink Ice' flowers derived from the same clonal propagation material but produced in a warmer production area were noted to be distinctly smaller. In addition, a slightly bronze sheen and a dark purple discoloration was noticeable on the inside of the tips of the inner bracts compared with the larger shinier pink inflorescences typical of cooler production areas (G. Nieuwoudt, personal communication). These color variants of 'Pink Ice' from warmer production areas are not favored by the export market, therefore resulting in lower prices.

The potential effect of predicted warming on the phenological events of 'Pink Ice' in an annual harvest cycle during the course of an entire production season, including the time of harvest, in comparison with the current production cycle is provided in Fig. 9. From March to July the sequence of events is similar for both current and elevated temperature scenarios, but differences become evident with the onset of spring budbreak and onward, with predicted delayed harvests in the late summer. Autumn-initiated inflorescences were harvested about a month earlier than inflorescences subtended by the spring flush (Fig. 9). As this is of significant 
commercial importance, further studies should aim to increase and favor the number of these shoots with inflorescences initiating in autumn, to reap the benefit of their desired advanced flowering times. Focus should be placed on the characterization of autumninitiated shoots, together with developing pruning regimes in combination with plant growth regulator applications, to promote inflorescence initiation on the autumn flush (Hoffman et al., 2009). In addition, autumninitiated inflorescences commence development during favorable temperature periods and flower quality is likely to be maintained even under slightly higher temperatures driven by climate change. However, the possibility exists that if the number of days above $35^{\circ} \mathrm{C}$ (maximum temperature for growth used in GDH calculation) increases as a result of climate change, flower initiation may shift from the spring flush to the summer flush (Louw et al., 2015) as photosynthetic rates decline significantly in Protea under these environmental conditions. It is unknown whether 'Pink Ice' would initiate inflorescences on a second summer flush, but should inflorescence initiation take place on the following autumn flush, the harvest period would again be favorable (Fig. 9).

The production of Cape flora under elevated mean and maximum temperatures associated with climate change is thus likely to be faced with reductions in yield due to shifts toward more vegetative growth along with delayed flowering and acute sunburn of the flowers (Smith et al., 2015). Deviation from current yields can also be expected due to a projected shifting in the seasonality of the rainfall from the current predominantly winter rainfall to a rainfall that would increasingly be more concentrated during the early summer, but possibly with a lower rainfall in the critical autumn rainfall period (Midgley et al., 2016). Although the impacts of possible water scarcity were not addressed in this study, this should form part of future research on climate change and Cape flora.

Management strategies involving the selection of potential production areas suitable for Protea cultivation or expanding to new selections on existing farms should take into consideration the possible changes in vegetative and reproductive growth and phenology that may accompany long-term climate projections. Differences in inflorescence quality defined by decreased width and dry weight, a delayed harvest time into autumn rather than late summer (Fig. 9), and the need to adjust pruning strategies to promote autumn-initiated inflorescences are some of the factors of importance when intending to produce Cape flora products of consistent high quality.

\section{Literature Cited}

Allen, S.E., H.M. Grimshaw, J.A. Parkinson, and C. Quarmby. 1974. Chemical analysis of ecological materials. Blackwell Scientific Publications, Oxford, UK.

Arnold, C.Y. 1959. The determination and significance of the base temperature in a linear heat unit system. J. Amer. Soc. Hort. Sci. 74:430445.

Causton, D.R. and M.P. Dale. 1990. The monomolecular and rectangular hyperbola as empirical models of the response of photosynthetic rate to photon flux density, with applications to three Veronica species. Ann. Bot. 380:389394.

Coetzee, J.H. and G.M. Littlejohn. 2001. Protea: A floricultural crop from the Cape Floristic Kingdom. Hort. Rev. 26:1-48.

Criley, R.A., P.E. Parvin, and S. Lekawatana. 1990. Flower development in Leucospermum cordifolium 'Vlam'. Acta Hort. 264:61-70.

Dische, Z. 1962. Color reactions of carbohydrates, $p$. 475-514. In: R.L. Whistler and M.L. Wolfrom (eds.). Methods in carbohydrate chemistry. Academic Press, New York, NY.

Gerber, A.I. 2000. Flower initiation and development in selected cultivars of the genus Protea. Stellenbosch University, South Africa, PhD Thesis.

Gerber, A.I., E.J. Greenfield, K.I. Theron, and G. Jacobs. 1995. Pruning of Protea cv. Carnival to optimise economic biomass production. Acta Hort. 387:99-106.

Gerber, A.I., K.I. Theron, and G. Jacobs. 2001a. Manipulation of flowering time by pruning of Protea cv. Sylvia ( $P$. eximia $\times P$. susannae). HortScience 36:909-912.

Gerber, A.I., K.I. Theron, and G. Jacobs. 2001b. The role of leaves and carbohydrates in flowering of Protea cv. Lady Di. HortScience 36:905-908.

Greenfield, E.J., K.I. Theron, and G. Jacobs. 1994. The effect of pruning on growth and flowering response of Protea cv. Carnival. J. S. Afr. Soc. Hort. Sci. 4:42-46.

Hamid, G.A., S.D. Van Gundy, and C.J. Lovatt. 1985. Citrus nematode alters carbohydrate partitioning in the 'Washington' navel orange. J. Amer. Soc. Hort. Sci. 110:642-646.

Hettasch, H.B., A.I. Gerber, and K.I. Theron. 1997. Pruning Protea cv. Carnival for biennial crops of improved yield and quality. Acta Hort. 453:127-133.
Hettasch, H.B. and G. Jacobs. 2006. Leucadendron are short-day plants: A preliminary report. Acta Hort. 716:113-116.

Hoffman, E.W. 2006. Flower initiation and development of Protea cv. Carnival. Stellenbosch University, South Africa, PhD Diss. (Agric.).

Hoffman, E.W., D.U. Bellstedt, and G. Jacobs. 2009. Exogenous cytokinin induces "out of season" flowering in Protea cv. Carnival. J. Amer. Soc. Hort. Sci. 134:308-313.

Hoffman, E.W. and G. Jacobs. 2010. Phenology of and heat unit requirements for growth in Protea 'Carnival' induced by benzyladenine-containing growth regulators. Acta Hort. 869:71-80.

Liang, S., X. Wu, and D. Byrne. 2017. Flower-size heritability and floral heat-shock tolerance in diploid roses. HortScience 52:682-685.

Louw, E-L., E.W. Hoffman, K.I. Theron, and S.J.E. Midgley. 2015. Physiological and phenological responses of Protea 'Pink Ice' to elevated temperatures. S. Afr. J. Bot. 99:93-102.

Malan, D.G. and G. Jacobs. 1990. Effect of photoperiod and shoot decapitation on flowering of Leucospermum 'Red Sunset'. J. Amer. Soc. Hort. Sci. 115:131-135.

Midgley, S.J.E., M. New, N. Methner, M. Cole, J. Cullis, S. Drimie, K. Dzama, B. Guillot, J. Harper, C. Jack, P. Johnston, T. Knowles, D. Louw, C. Mapiye, H. Oosthuizen, J. Smit, and D. van den Broeck. 2016. A status quo review of climate change and the agriculture sector of the Western Cape Province. Report submitted to the Western Cape Department of Agriculture and the Western Cape Department of Environmental Affairs \& Development Planning. African Climate \& Development Initiative, University of Cape Town, Cape Town, South Africa.

Nieuwoudt, G. and G. Jacobs. 2010. Time of pruning affects yield, flowering time and flower quality of Protea 'Pink Ice'. Acta Hort 869:63-70.

Reed, A.B., C.J. O'Connor, L.D. Melton, and B.G. Smith. 2004. Determination of sugar composition in grapevine rootstock cuttings used for propagation. Amer. J. Enol. Viticult. 55: 181-186.

Rieger, M.A. and M. Sedgley. 1996. Effect of daylength and temperature on flowering of the cut flower species Banksia coccinea and Banksia hookeriana. Aust. J. Expt. Agr. 36:747-753.

SAS Institute Inc. 2003. SAS 9.1.3, service pack 4. Cary, NC.

Sedgley, M. and A.M. Fuss. 1992. Correct pruning lifts Banksia yields. Austral. Hort. 90:50-53.

Smith, A., W.J. Steyn, and E.W. Hoffman. 2015 Involucral bract browning in Proteas - The what, how and what now? Acta Hort. 1097:125-132.

Webster, A.D. 2005. Shoot growth. In: J. Tromp, A.D. Webster, and S.J. Wertheim (eds.). Fundamentals of temperate zone tree fruit production. Backhuys Publishers, Kerkwerve, The Netherlands. 